\title{
Mitä on humanismi?
}

\author{
Urpo Harva: Inhimillinen ih- \\ minen - Homo humanus. \\ Humanistisia tarkasteluja. \\ WSOY: Juva 1983.
}

\begin{abstract}
'Was ist der Mensch? Mikä on ihminen?'” Tämä filosofisen antropologian peruskysymys, sen asettaminen, sen tarkastelu eri puoliltaan ja osin siihen vastaaminenkin on prof. Harvan kirjallisen tuotannon ydinaiheita. Erityisesti 1950-luvulla, syrjässä loogisen empirismin ja analyyttisen filosofian valtavirrasta, kehitteli hän näitä teemoja lukuisissa kirjoissaan (esim. Yksilö ja yhteisö 1954; Ihminen etsii itseään 1957; Moraali ja yhteiskunta 1957; Etiikka 1958.) Myös humanismiin liittyvät kysymykset saavat sijansa Harvan kirjoituksissa jo tällöin. Esimerkiksi Suomalaisessa Suomessa (4/1952) ja Parnassossa (2/1955) Harvalla oli tästä aiheesta mainiot esseet. Eläkevuosinaan Harva on palannut samojen peruskysymysten äärelle: vuonna 1978 hän julkaisi teoksen $H y$ vä ja paha, praktisen etiikan ongelmia, ja tänä vuonna po. teoksen Inhimillinen ihminen - Homo humanus.
\end{abstract}

Harva asettaa tehtäväkseen selvittää mitä humanismi on. Tämä onkin mitä tarpeellisin tehtävä, sillä humanismi-käsi- te on kärsinyt melkoisen inflaation menettämällä täsmällisen sisältönsä. Näin on käynyt siksi, että toisen maailmansodan jälkeen humanismin suosio on kasvanut sellaisiin mittoihin, että kaikki haluavat nykyisin olla humanisteja. Emme kuitenkaan enää tiedä mitä ajatella humanismista, kun lähes päivittäin saamme kuulla joukkoviestimistä vakuutteluja "We got there just in time", jota humanismi voisi säilyä tai toteutua - milloin Grenadassa tai Varsovassa, milloin Falklandeilla tai Kabulissa. Niinpä sopiikin näin Orwellin vuoden aattotunnelmissa lukea tekstiä, jolla on sama tarkoitus kuin hänelläkin: vähentää epäselvää ja tosiasioita hämärryttävää kielenkäyttöä.

Harva tarkastelee kirjassaan humanismi-käsitteen historiallisia juuria, antiikin humanismia, renesanssihumanismia, uushumanismia ja meidän aikamme erilaisia humanismeja: kristillistä, marxilaista ja naturalistista humanismia. Kirjan lopussa tarkastelu laajenee tieteen ja filosofian yhteyksiin ja humanis- min tulevaisuuden näkymiin.

Yhtä paljon kuin teos on humanismi-käsitteen selvittelyä, on se myös ihmisen olemuksen, Sven Krohnin sanoin, ydinihmisen, määritelmän ja ominaisuuksien etsintää. Näkisin sen myös Harvan persoonallisena yhteenvetona siitä monikymmenvuotisesta ajattelutyöstä, jota hän on tähän kysymykseen liittyen tehnyt. Kirja on myös oiva osoitus siitä, miten ihmiseen liittyvät filosofiset ongelmat ovat yhteydessä filosofian muiden osa-alueiden, tietoteorian ja etiikan ongelmiin, ja ratkeavat vain mikäli nämä muutkin ongelmat voidaan tyydyttävästi ratkaista.

Antiikin klassinen humanismi on Harvalle kaiken humanismin alku ja ydin. Sitä hän käyttää arviointiperustanaan muita humanismeja tarkastellessaan. Antiikin humanismin hahmottelema ihmiskäsitys, ihmisen ideaali, on myös Harvan oman, persoonallisen ihmiskäsityksen olennainen osa. Antiikin humanismi sellaisena kuin se esiintyy erityisesti Platonin ja Aristoteleen ajatuksissa on 
samalla kirjan parasta antia.

Humanismin tarkastelu aloitetaan siitä historiallisesta tilanteesta, jolloin ihminen ensi kertaa syvemmin heräsi huomaamaan oman erityisluonteensa maailman muiden olioiden joukossa, pohtimaan omaa olemustaan. Tämä tapahtui noin 500 vuotta ennen ajanlaskumme alkua varsin yhtäaikaisesti kolmessa erilaisessa kulttuuripiirissä: Kiinassa, Intiassa ja Kreikassa. Voimakkaimmin näistä vaikutti länsimaisen ihmisen ajattelutapaan juuri kreikkalainen ajattelu, mikä näkyy sittemmin myös muissakin humanismin muodoissa.

Erotuksena Kiinan ja Intian filosofioista antiikin Kreikan ajattelulle on ominaista ihmisen vapauden korostaminen. Vapaus ei merkinnyt ainoastaan ulkoista vapautta: että yhteiskunta salli yksilön toimia parhaaksi katsomallaan tavalla, vaan myös, ja erityisesti sisäistä vapautta: että ihminen kykenee järkensä avulla vapauttamaan myyteistä ja uskomuksista, ja että voi kriittisesti tarkastella sitä mitä kulttuuri kasvatuksen välityksellä on häneen juurruttanut. Tämä merkitsi nykyaikaisessa mielessä tieteellisen ajattelun syntymistä.

Järjen, logoksen, korostaminen voi esille myös asian toisen puolen, ihmisen vajavuuden ja tietämättömyyden, mistä kreikkalainen tragedia sai tyypillisen perusaineksensa - ihmisen ahdistuksen ja kärsimyksen. Mutta vaikka kreikkalaiset pitivätkin ihmistä rajallisena, heikkona olentona, uskoivat he myös että ihmisessä on ikuinen pyrkimys johonkin parempaan, korkeampaan: Jumalaan ihmisessä kuten Platon ja Aristoteles ajattelivat. Ihmisellä on niinmuodoin oma absoluuttinen arvonsa, jota mitkään muut arvot eivät voi syrjäyttää. Tälle absoluuttiselle ihmisen arvolle rakentuu myös käsitys ihmisen peruuttamattomista oikeuksista.

Ihmisen pyrkimys parem- paan ei kuitenkaan ole luontoperäistä siinä mielessä kuin luonnossa ja eläimissä havaittava kasvu, vaan ihmisen on itse kehitettävä itseään, "tultava siksi mikä hän on'. Tämä tapahtuu paideian, kreikkalaisen yleissivistävän kasvatuksen avulla. Ammattisivistys ei sensijaan kuulunut paideiaan. Käsityksen taustalla oli kreikkalaisten kielteinen suhtautuminen työhön, joka oli epävapaata toimintaa ja sopii vain orjille. Vapaille miehille kuului vapaa-aika, mikä ei suinkaan merkinnyt joutilasta laiskottelua vaan kontemplaatiota, olevaisuuden, kokonaisuuden pyyteetöntä tarkastelua, teoreettista elämäntapaa. Harva onkin useassa yhteydessä esittänyt, että nykyisestä työyhteiskunnan kriisistä voidaan päästä vain omaksumalla antiikin aristotelinen työn filosofia.

Kreikasta antiikin humanismi siirtyi Roomaan saaden siellä uusia piirteitä, esim. paideiassa korostettiin sen eettistä puolta. Rooman valtakunnan tuhouduttua antiikin kulttuuri unohtui useiksi vuosisadoiksi kristinuskon tullessa kulttuurin valtavirtaukseksi.

Keskiajan loppupuolella, 1300-luvulta alkaen elpyi antiikin kulttuuriharrastus Italiassa erityisesti Danten (12651321), Petrarcan (1304-1374) ja Pico della Mirandolan (1463-1494) sekä pohjoisemmassa Euroopassa Erasmus Rotterdamilaisen (1466-1536) ansiosta. Tätä aikakautta alettiin kutsua renessanssiksi, uuden syntymisen ajaksi. Renesanssille oli ominaista usko, että antiikin kulttuurin elvyttäminen voisi tuoda uutta elinvoimaa kirkon kahlehtimaan henkiseen elämään. Tosin jo ennen renesanssia oli antiikin ajattelutapa päässyt vaikuttamaan Euroopan hengenperintöön kun Tuomas Akvinolainen (1225-1274) liitti yhteen aristotelista ajattelua ja kristinuskoa. Onkin sanottu, että ilman Tuomasta ei renesanssihumanismista olisi tullut sitä mitä siitä tuli. Toinen nk. kristillisen humanismin klassinen edustaja oli saksalainen mystikko Mestari Eckhart (n. 1260-1327), joka pääpiirteissään edusti akvinolaista ajattelua.

Renesanssin humanismia luonnehtii ehkä parhaiten sanapari: vita activa - l'uomo universale. Tällöin arvostettiin toimeliasta ja aktiivia elämää vastakohtana aikaisemmalle kirkon korostamalle askeettiselle, yksinäisyyteen ja passiivisuuteen vetäytymään pyrkivälle asenteelle, ja korostettiin ihmisen luonnollista uteliaisuutta, kaiken tietämään ja kaiken osaamaan pyrkivää ihmistä. Renesanssihumanismi loi henkiset edellytykset nykyaikaisen luonnontieteen synnylle.

Renesanssin jälkeen antiikin kulttuurin harrastus virkosi uudestaan 1800-luvun taitteessa Saksassa, mistä humanismi -termikin on peräisin. Tätä uushumanismiksi kutsuttua virtausta edustivat $\mathrm{mm}$. Goethe, Lessing, Schiller, von Humbolt ja Herder. Epäilemättä uushumanististen ajatusten vaikutuspiirissä oli ainakin jossain määrin myös Karl Marx.

Marxilaisen humanismin yleinen luonnehdinta on samalla tavoin ongelmallista kuin marxilaisuuden yleensä: ei ole mitään yhtä yleisesti hyväksyttyä käsitystä marxilaisuudesta. Marxismi on aikojen kuluessa muotoutunut ja eriytynyt useiksi erilaisiksi käsityksiksi siitä mikä Marxin (Engelsin ja Leninin) opeissa on olennaista ja kestävää. Tämän mukaisesti voidaan myös marxilaisessa humanismissa löytää erilaisia versioita. Harva tekee perinteisen eron revisionistisen ja ortodoksisen tulkinnan välille, mutta käyttää tarkasteluissaan myös jakoa "nuoreen" ja 'kypsään" Marxiin.

Varhaiskirjoituksissaan (1840-luvulla) Marx esitti tunnetun vieraantumisteoriansa, mikä ei Harvan mukaan olisi mahdollista ellei Marx olisi 
klassisen humanismin perinteiden nukaisesti olettanut ihmiselle muuttumatonta olemusta, josta kapitalismi sitten ihmisen vieraannuttaa. Tämä on Harvan mukaan marxilaisen humanismin välttämätön ehto. Marxin kypsän kauden tuotannossa jää vieraantumisteema selvästi taka-alalle nk. poliittisen taloustieteen kritiikin (Pääoma ja sen esityöt) tullessa tarkastelujen keskiöön. Ihmisen ja yhteiskunnan historiallisen ehdollisuuden korostuminen saa mm. ranskalaisen Luis Althusserin puhumaan Marxin teoreettisesta antihumanismista, eli siitä, että Marx myöhäisemmässä tuotannossaan kieltää ihmisen muuttumattoman olemuksen. Harva ei yhdy tähän tulkintaan. Oman käsitykseni mukaan Marxin nuoruuden kirjoituksissa, kun ne riisutaan saksalaiselle filosofialle ominaisesta puheenparresta, on voimakas painotus ihmisen olemuksen, ei pysyvästä, vaan historiallisesti ja yhteiskunnallisesti määräytyvästä, muuttuvasta luonteesta. Esim. Marxin tunnetut Feuerbach-teesit (1845, erit. 6.) ovat tästä hyvänä osoituksena.

Marxilais-leniniläinen ortodoksinen humanismi poikkeaa Harvan mukaan huomattavasti klassisen humanismin esittämistä käsityksistä $\mathrm{mm}$. ihmisarvon, vapauden ja moraalinormien suhteen ja saa näin ollen häneltä kriittisen arvion.

Naturalistinen humanismi perustuu monistiseen katsomukseen, jonka mukaan on olemassa vain luonto, ja ihminen on sen eräs osa. Ei ole olemassa mitään luonnon ulko- tai yläpuolella olevaa - ei ideaaleja, arvoja, Jumalaa. Ihminen osana muuta luontoa on evoluution tulosta. Vähittäisen kehityksen myötä hänestä on tullut älyllinen, toimintaansa ohjaava ja kontrolloiva, vapaa olento ja luonnon kehityksen kärki. Tässä asemassa ihmiselle lankeaa vastuu sekä itsensä että muun luonnon tulevaisuudesta. Tämän vastuun tiedostamisen uskotaan yhdistävän koko ihmiskunnan. Syntyy evoluutioteoriaan pohjaava uusi maailmankatsomus "uskonto ilman ilmoitusta", kuten Julian Huxley, tunnettu englantilainen biologi asian ilmaisi. Pelkästään luonnontieteiden tuloksille ei Harvan mielestä kuitenkaan humanistista käsitystä voida rakentaa, jos humanismissa otetaan kantaa myös arvo- ja ihmisen olemuskysymyksiin.

Lopuksi otan esiin pari seikkaa, jotka samalla valottanevat kirjan lopussa käsiteltäviä humanismin, tieteen ja filosofian yhteisiä ongelmia.

Harva rajaa Heideggerin tavoin tarkastelun sellaisiin humanismin muotoihin, joissa voidaan tehtä ero inhimillisen ja epäinhimillisen ihmisen välillä. Erottelu on tärkeä sekä ontologisesti että metodologisesti, sillä se edellyttää Harvan mukaan muuttumattoman ihmisluonnon olettamista. Ihminen käyttäytyy inhimillisesti silloin, kun hän käyttäytyy (muuttumattoman) olemuksensa mukaisesti. Näin esim. Sartren edustama eksistentialistinen humanismi, joka rakentuu täydellisesti vapaan ihmisen idealle, jätetään tarkastelun ulkopuolelle.

Erottelu on anologinen Harvan esittämän moraalin ja tiedon määritelmien kanssa (ks. Etiikka 1958, 22-23): moraali on hyvän ja pahan, tieto toden ja epätoden erottamista toisistaan. Jotta hyvä ja paha voidaan erottaa, on edellytettävä, että ihmisellä on tähän erotteluun kykenevä moraalitajunta. Jotta tosi ja epätosi voidaan erottaa, on edellytettävä että ihminen on järkevä, rationaalinen olento. Harvan ajattelutapa on siis selkeästi essentialistinen.

En ole lopultakaan aivan varma missä merkityksessä Harva käyttää sanaa inhimillinen, deskriptiivisessä vai normatiivisessa mielessä, ja että voiko sitä käyttää yleensä muussa kuin jälkimmäisessä. Mikäli inhimillinen on normatiivinen käsite, palautuu kysymys hyvän ja pahan erotteluun, etiikan ongelmaksi. Mikäli inhimillinen on deskriptiivinen käsite, palautuu kysymys kuvauksen totuudellisuuden ongelmaksi, 1. tässä tapauksessa kysymykseksi inhimillisen kriteeristä, tietoteorian ongelmaksi.

Mikäli inhimillinen on deskriptiivinen käsite, palauttuu kysymys kuvaukseen totuudellisuuden ongelmaksi, 1 . tässä tapauksessa kysymykseksi inhimillisen kriteeristä, tietoteorian ongelmaksi.

Mikä on siis inhimillisen kriteeri? Humanismin veristinen ja arvovapaa tiedekäsitys on tähän keskeiseen käsitteeseen sovellettuna selvästi ongelmallinen. Humanismiin itseensä liittyvät käsitteet ovat arvopitoisia käsittääkseni samaan tapaan kuin puhutaan "'puhtaan havainnon" mahdottomuudesta sanomalla, että havainnot ovat aina "teoriapitoisia".

Palatakseni kirjan loppuun:

Onko ihmisen täydellinen humanisoituminen yleensä mahdollista. Voiko hän tulla olemuksensa mukaiseksi? Klassinen humanismi kieltää tämän. Mutta ihmisen kaipuu ja pyrkimys täyteen inhimillisyyteen säilyy. Sitä elähdyttää toivo, jonka "'peruste on siinä kokemuksen lujittamassa uskossa, että ihmistä voidaan jalostaa inhimillisemmäksi sen toiminnan avulla, jota me voimme nimittää sivistäväksi kasvatukseksi ja josta kreikkalaiset käyttivät sanaa paideia."

Rainer Aaltonen 